\title{
Czas w kapłańskim opowiadaniu o stworzeniu: dzień czwarty (Rdz 1,14-19)
}

\author{
Time in the Priestly Creation Narrative: The Fourth Day (Gen 1:14-19)
}

\author{
KRZYSZTOF NAPORA \\ Katolicki Uniwersytet Lubelski Jana Pawła II \\ krzysztof.napora@kul.pl, ORCID: 0000-0002-7923-4517
}

\begin{abstract}
Streszczenie: Organizacja kosmosu w wymiarze czasowym (temporalnym) wydaje się stanowić istotny, choć niekiedy ignorowany, element kapłańskiego opowiadania o stworzeniu (Rdz 1,1-2,4a). Jej logika opiera się na osi wyznaczonej przez pierwszy, czwarty, i siódmy dzień stworzenia: powstanie światła, stworzenie ciał niebieskich, wreszcie konsekrację szabatu. W artykule tym autor podejmuje krytyczną refleksję nad centralnym elementem osi, na której wspiera się temporalna organizacja kosmosu: opisem czwartego dnia stworzenia (Rdz 1,14-19). Analizując strukturalny i semantyczny wymiar opisu stworzenia ciał niebieskich autor uwypukla ich wyjątkowe miejsce i niepowtarzalną rolę w kapłańskim opowiadaniu o stworzeniu świata.
\end{abstract}

Słowa kluczowe: kapłańskie opowiadanie o stworzeniu, Heptameron, Rdz 1,14-19; Rdz 1; Rdz 1-11, ciała niebieskie, czas

\begin{abstract}
The temporal organization of the cosmos seems to be an important, though sometimes ignored, element of the priestly creation narrative in Gen 1,1-2,4a. Its logic is based on the axis determined by the first, fourth, and seventh days of creation: the creation of luminaries, of celestial bodies, and finally the consecration of the Sabbath. In this article, the author takes up a critical reflection on the central element of the axis: the description of the fourth day of creation in Gen 1,14-19. In analyzing the structural and semantic dimensions of this text, the author emphasizes the unique place and role of the celestial bodies in the description of the created world.
\end{abstract}

Keywords: priestly creation narrative, Heptaemeron, Gen 1:14-19; Gen 1; Gen 1-11, heavenly bodies, time

Obraz przestrzennej organizacji kosmosu wydaje się być dominujący w kapłańskim opowiadaniu o stworzeniu zawartym w Rdz 1,1-2,4a. Uważna lektura tego utworu pozwala jednakże odkryć przedstawione w nim - być może w sposób nieco bardziej dyskretny - elementy, które wskazują na organizację kosmosu w wymiarze czasowym.

Elementy organizacji czasowej zostały podkreślone w newralgicznych momentach procesu stwarzania świata: u jego początku (dzień pierwszy - Rdz 1,3-5), w połowie (dzień czwarty - Rdz 1,14-19), wreszcie w opisie jego zakończenia (dzień siódmy - Rdz 2,2-3). Kontynuując naszą refleksję na temat czasu w kapłańskim 
opowiadaniu o stworzeniu ${ }^{1}$, w niniejszym artykule pragniemy skoncentrować naszą uwagę na opisie ujętym w kadr dnia czwartego (zob. Rdz 1,14-19). W pierwszej części naszej analizy zajmiemy się miejscem dnia czwartego w strukturze Heptameronu (1.1) i przyjrzymy się modelom struktury perykopy Rdz 1,14-19 (1.2). W drugiej części artykułu rozważymy „zawartość” kadru dnia czwartego. Zwrócimy uwagę na elementy polemiczne w opowiadaniu o stworzeniu ciał niebieskich (2.1), a następnie omówimy specyficzną rolę ciał niebieskich w temporalnej organizacji stworzonego świata (2.2).

\section{Strukturalny wymiar stworzenia ciał niebieskich}

Komentując pierwszy rozdział Księgi Rodzaju, Dariusz Dziadosz ${ }^{2}$ pisze: „ten przepiękny pod względem struktury i formy literackiej poemat jest jednocześnie głęboką teologiczną wizją". Poszukując teologicznej wizji wyrażonej w stworzeniu ciał niebieskich chcemy rozpocząć od umiejscowienia go na tle Heptameronu (1.1) oraz przyjrzeć się dokładniej strukturze opisu dnia czwartego (1.2).

\subsection{Dzień czwarty w strukturze Heptameronu}

Analiza zagadnienia czasu w kapłańskim opowiadaniu o stworzeniu nieuchronnie kieruje naszą uwagę na opis czwartego dnia stworzenia:

${ }^{14}$ A potem Bóg rzekł: «Niechaj powstaną ciała niebieskie, świecące na sklepieniu nieba,
aby oddzielały dzień od nocy, aby wyznaczały pory roku, dni i lata; ${ }^{15}$ aby były ciałami
jaśniejącymi na sklepieniu nieba i aby świeciły nad ziemią». I tak się stało. ${ }^{16}$ Bóg uczynił
dwa duże ciała jaśniejące: większe, aby rządziło dniem, i mniejsze, aby rządziło nocą, oraz
gwiazdy. ${ }^{17}$ I umieścił je Bóg na sklepieniu nieba, aby świeciły nad ziemią; ${ }^{18}$ aby rządziły
dniem i nocą i oddzielały światłość od ciemności. A widział Bóg, że były dobre. ${ }^{19}$ I tak
upłynął wieczór i poranek - dzień czwarty (Rdz $1,14-19)^{3}$.

Dzieło, jakiego Stwórca dokonuje w tym dniu, jest jednym z tych elementów stworzenia, któremu redaktor kapłański poświęca najdłuższy opis. Aby przedstawić stworzenie „ciał niebieskich świecących na sklepieniu nieba” (מארת ברקיע השמים Rdz 1,14) potrzebuje on aż sześciu wersetów. Jeśli chodzi o pozostałe dzieła, po-

\footnotetext{
Pierwszy jej etap w odniesieniu do dnia pierwszego znaleźć można w Napora, „Czas w kapłańskim opowiadaniu o stworzeniu," 13-37.

Dziadosz, Tak było, 19.

Tłumaczenie według piątego wydania Biblii Tysiąclecia (BT).
} 
dobna wylewność towarzyszy jedynie opisowi stworzenia człowieka (1,26-31), choć w tym wypadku należy stwierdzić, że człowieka dotyczą bezpośrednio jedynie wersety 26-294. Długość opisu dotyczącego dzieła wykonanego w dniu czwartym wcale nie oznacza jakiejś szczególnej dokładności przekazu redaktora kapłańskiego na temat procesu stwarzania ciał niebieskich. Wynika ona przede wszystkim z faktu zastosowania przez niego powtórzenia myśli dotyczącej funkcji ciał niebieskich ${ }^{5}$. W powtórzeniu tym, jak stwierdza Janusz Lemański, egzegeza historyczno-krytyczna dostrzegała ślad podwójnej tradycji (Wortbericht i Tatbericht): „Bóg najpierw stwarza słowem (ww. 14-15), a potem wydaje się powtarzać ten sam akt, czyniąc (w. 16) i umieszczając stworzone przez siebie światła na sklepieniu nieba" ${ }^{6}$. Niezależnie jednak od skomplikowanej historii redakcji tego tekstu, nie sposób nie dostrzec w obecnym w perykopie powtórzeniu, nacisku na szczególne znaczenie, jakie redaktor biblijny przypisuje powstaniu i roli ciał niebieskich ${ }^{7}$.

$\mathrm{Na}$ to szczególne znaczenie wydaje się wskazywać szereg czynników. Jednym $\mathrm{z}$ nich jest miejsce, jakie dzień czwarty zajmuje w strukturze Heptameronu. Istnieje wiele modeli, które próbują opisać tę strukturę. Jednym z najbardziej popularnych jest model dyptyku, w którym sześć pierwszych dni stworzenia podzielić można na dwie triady (1-3 i 4-6), określane odpowiednio jako „dzieło różnicowania” (opus dictinctionis) i „dzieło dekorowania” (opus ornatus). Według tego modelu dzień czwarty rozpoczyna drugi etap dzieła stworzenia, analogicznie do dnia pierwszego, który inauguruje etap pierwszy. Jednakże dzień czwarty stanowi paralelę dnia pierwszego - ewidentnie wyróżnionego w kapłańskim opowiadaniu o stworzeniu ${ }^{8}$ - również w szerszym znaczeniu. Podobieństwo między nimi ma przede wszystkim charakter materialny - dotyczący „zawartości” obu tych dni. Stwarzając światło w dniu pierwszym i oddzielając je od ciemności, Bóg inauguruje rytm przemiany dnia i nocy. Analogicznie, stwarzając ciała niebieskie, Bóg umieszcza je na sklepieniu nieba, ,aby oddzielały dzień od nocy”, „aby były ciałami świecącymi na sklepieniu nieba i aby świeciły nad ziemią". Oprócz tego jednak oba dni łączy również pewne podobieństwo o charakterze formalnym. W swojej książce Création et séparation. Étude exégétique du chapitre premier de la Genèse Paul Beauchamp, analizując powtarzalność użytych przez redaktora kapłańskiego w Rdz 1 formuł, wyróżnił dziesięć jednostek, które nazwał kadrami. Na pełny kadr składa się jego zdaniem 7 elementów:

1. zapowiedź komendy: „Bóg rzekł” (10 razy: Rdz 1,3.6.9.11.14.20.24.26.28.29);

2. słowo polecenia: „Niech się stanie” (Rdz 1,3.6.14), „niech się zbiorą” (Rdz 1,9), „nie się ukaże” (Rdz 1,9) etc.;

\footnotetext{
Zob. Vogels, „The Cultic”, 174.

Zob. Westermann, Genesis 1-11, 126.

Lemański, Księga Rodzaju 1-11, 158; zob. Schmidt, Die Schöpfungsgeschichte, 109-117.

Zob. Wenham, Genesis 1-15, 21.

Zob. Lakhmitskaya - Napora, „I widział Bóg”, 19-30.
} 
3. formuła wykonania: „I stało się światło” ( $\mathrm{Rdz} \quad 1,3)$, „i stało się tak” $(\operatorname{Rdz} 1,7.9 .11 .15 .24 .30)$;

4. wykonanie: „Bóg uczynił” (Rdz 1,7.16.25), „Bóg umieścił” (Rdz 1,17), „Bóg oddzielił” (Rdz 1,4.7), „Bóg stworzył” (Rdz 1,21.27);

5. ocena: Bóg widział, „światło, że było dobre” ( $\operatorname{Rdz} 1,4)$, „że było dobre” (Rdz 1,5.10.12.18.21.25), „że wszystko co stworzył było bardzo dobre” (Rdz 1,31);

6. dalsze słowa: „I nazwał Bóg” (Rdz 1,5.8.10), „i błogosławił Bóg” (Rdz 1,22.28);

7. wzmianka o dniu: „był wieczór i był poranek $x$ dnia” ( $\operatorname{Rdz} 1,5.8 .13 .19 .23 .31)^{9}$.

Jednocześnie Beauchamp zauważa, że jedynie w przypadku dnia pierwszego mamy do czynienia z kompletnym kadrem, w którym zidentyfikować można wszystkie siedem elementów. Należy jednak zauważyć, że w opisie stworzenia ciał niebieskich do pełnego kadru brak jedynie elementu szóstego: Bóg - inaczej niż w przypadku światła i ciemności - nie nazywa swego dzieła. Redaktor biblijny wspomina jedynie duże i małe ciało świecące, rządzące odpowiednio dniem i nocą, oraz gwiazdy $(1,16)$. Choć podobnie jak w przypadku pozostałych dni, aktywność Stwórcy rozpoczyna się od formuły rozkazu wyrażonej w formie jussivu (יהי - „niech się stanie”), to jednak warto zauważyć, że w przypadku dnia czwartego jest to forma czasownika היה, „być, stać się”, który występuje również w dniu pierwszym (Rdz 1,3) oraz drugim ( $\operatorname{Rdz}$ 1,6 - w wierszu tym dwukrotnie). Podobieństwo formuły rozkazu jest tym bardziej uderzające, że w przypadku dnia czwartego wiąże się z pewną nieregularnością gramatyczną: czasownik היה użyty został w liczbie pojedynczej, pomimo że podmiot (מארת - „ciała świecące”) występuje w liczbie mnogiej ${ }^{10}$. Aktywność Boga w dniach pierwszym, drugim i czwartym dotyczy przede wszystkim „porządku kosmicznego" i „sfery niebiańskiej”. Co ciekawe, to właśnie w tych trzech dniach pojawia się również idea separacji, wyrażona czasownikiem בדל, „oddzielać, rozdzielać” ${ }^{11}$.

Alternatywny model struktury Heptameronu łączy dni w dwie grupy według nieco innego kryterium. Dni od pierwszego do czwartego tworzą tzw. „fazę kosmologiczną" (cosmological phase), ponieważ w tym czasie powstaje struktura kosmosu. Dni piąty i szósty tworzą tzw. „fazę ożywioną” (animate phase), ponieważ dokonuje się w nich proces powstawania organizmów żywych. Beauchamp zauważa, że na każdą z tych faz przypada podobna liczba słów w tekście hebrajskim (odpowiednio 207 i 206). Każda z nich obejmuje również po „pięć stwórczych słów Boga”'12. Według tego podziału dzień czwarty zamyka fazę kosmologiczną, tworząc rodzaj inkluzji z dniem pierwszym poprzez przywołanie szeregu terminów, takich jak: „światło”

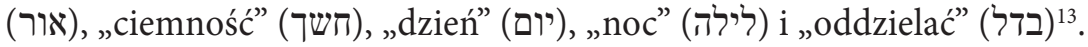

\footnotetext{
Zob. Beauchamp, Création, 21-26.

Zob. GKC, 145o.

Zob. Beauchamp, Création, 53-54.

Zob. Beauchamp, Création, 66-69.

Zob. Sasson, „Time”, 186.
} 
Gwoli uzupełnienia, oprócz modelu struktury, według którego dzień czwarty stanowi początek drugiej fazy stworzenia, czy też modelu, według którego stanowi on koniec pierwszej fazy procesu, należy również wspomnieć o próbach dostrzeżenia w nim czegoś w rodzaju punktu centralnego (pivotal day) całego opowiadania ${ }^{14}$. Jak pisze Walter Vogels, ,if one regards the story as a presentation of a seven day week, then the fourth day stands in the middle. It is really Mittwoch, both preceded and followed by three other days"15. Dzien czwarty bowiem, nie tylko nawiązuje do dnia pierwszego poprzez wzmiankę o alternacji dnia i nocy, ale wydaje się również posiadać charakter proleptyczny w stosunku do dnia siódmego, zapowiadając święta o charakterze liturgicznym ${ }^{16}$. Jak zostało wskazane wyżej, pewne elementy dnia czwartego nawiązują do dnia drugiego (czasowniki בדל i בדי), jednocześnie inne wydają się wskazywać na podobieństwo między stworzeniem ciał niebieskich i stworzeniem człowieka w dniu szóstym (czasownik נתן, „umieścić, dać” z ל w Rdz 1,17.29; idea sprawowania władzy wyrażona przez משל w Rdz 1,17 oraz רדה w Rdz 1,26.28).

W ten sposób, niezależnie od przyjętego modelu, dzień czwarty okazuje się być istotnym elementem struktury opowiadania, czymś w rodzaju klucza sklepienia (le clé de voûte), centralnym fragmentem w ciągu punktów, na których opiera się idea organizacji kosmosu w wymiarze czasowym (temporalnym), skonstruowana na podstawie dni: pierwszego, czwartego i siódmego ${ }^{17}$.

\subsection{Struktura czwartego dnia stworzenia}

Nie tylko pozycja dnia czwartego w strukturze Heptameronu dzieli egzegetów. Również w odniesieniu do struktury opisu czwartego dnia stworzenia zajmują oni różne - skrajne niekiedy - stanowiska. Wielu egzegetów, analizując tekst w perspektywie diachronicznej, podkreśla jego kompozycyjny charakter i wskazuje na widoczny w omawianej perykopie brak uporządkowania, zamieszanie i liczne ślady przeróbek redakcyjnych ${ }^{18}$. Inni, przyjmując raczej perspektywę synchroniczną, podkreślają, że „akapit czwartego dnia ukazuje piękną i harmonijną strukturę"19.

Struktura narracyjna dnia czwartego bywa przedstawiana jako linearna sekwencja czasowników w formie wayyiqtol, mających Boga jako podmiot i opisujących Jego stwórcze działanie ${ }^{20}$. Pierwszy czasownik ויאמר (,powiedział”) inauguruje fazę

14 Zob. Sasson, „Time”, 186.

15 Vogels, „The Cultic”, 176. Jak zauważa Walter Vogels, liczba cztery ma sama w sobie znaczenie symboliczne. Jest ona liczbą kosmiczną: cztery strony świata, cztery pory roku, cztery rzeki wypływjące z ogrodu Eden (Rdz 2,10)". Ibidem, 176.

16 Rudolph, Israel's Festivals, 112.

17 Zob. Beauchamp, Création, 67.

18 Zob. Gunkel, Genesis, 100; Skinner, Genesis, 26; von Rad, Die Priesterschrift, 13.

19 Vogels, „The Cultic”, 170; Zob. również Ricoeur, „On the Exegesis”, 141; Wenham, Genesis 1-15, 21-22.

20 Zob. Pawłowski, Opowiadanie, 317. 
ויתן - ויעש - (,uczynił”) otwiera fazę wykonania. Trzeci wreszcie („umieścił”) opisuje instalację ciał niebieskich na sklepieniu nieba. Całość zamyka czasownik וירא (,widział”), wskazujący etap ewaluacji. Czasownikom tym podporządkowane są zdania i formuły celowe. Całość można przedstawiać w następujący sposób $^{21}$ :

\section{Faza planowania $(\mathrm{Rdz} 1,14-15)$}

A potem Bóg rzekł (ויאמר)

„Niechaj powstaną ciała niebieskie...”

aby oddzielały

aby wyznaczały

aby świecily

\section{Faza wykonania $(\operatorname{Rdz} 1,16)$}

Bóg uczynił (ויעש) dwa duże ciała jaśniejące większe

aby rządziło dniem

i mniejsze

aby rządziło nocą

oraz gwiazdy

\section{Faza instalacji (Rdz 1,17-18)}

I umieścił (ויתן) je Bóg na sklepieniu nieba

$$
\begin{aligned}
& \text { aby świeciły } \\
& \text { aby rządziły } \\
& \text { aby oddzielały }
\end{aligned}
$$

\section{Faza ewaluacji (Rdz 1,18$)$}

A widział (וירא) Bóg, że były dobre.

Obecność zdań i formuł celowych niewątpliwie wyróżnia dzień czwarty na tle pozostałych dni tygodnia w Rdz 1,1-2,4a. W przypadku dnia czwartego redaktor biblijny informuje nie tylko o fakcie stworzenia, ale również o przeznaczeniu (funkcji) poszczególnych stworzeń. Czyni to poprzez użycie przyimka ל, który w połączeniu $\mathrm{z}$ rzeczownikiem lub czasownikiem $\mathrm{w}$ formie bezokolicznika (infinitivus constructus) tworzy zdania lub wyrażenia określające kierunek, cel lub funkcję ${ }^{22}$. Przyimek ten aż jedenaście razy pojawia się w Rdz 1,14-19. To właśnie dystrybucja zdań celowych stała się dla egzegetów podstawą do wyodrębnienia w omawianej perykopie mniej lub bardziej regularnych modeli struktury o charakterze chiastycznym lub

21 Por. Vogels, „The Cultic”, 171-172.

22 DCH IV, 481-482. 
palistroficznym. Przykładem regularnego modelu koncentrycznego jest choćby ten zaproponowany przez Gordona J. Wenham’a, który w następujący sposób prezentuje wskazane w tekście funkcje ciał niebieskich:

A aby oddzielać dzień od nocy (14a)

B aby wyznaczały pory roku' ${ }^{23}$, dni i lata (14b)

C aby świeciły nad ziemią (15)

D aby rządziło dniem (16a)

D’ aby rządziło nocą (16b)

Bóg uczynił dwa światła

C’ aby świeciły nad ziemią (17)

B' aby rządziły dniem i nocą (18a)

A’ aby oddzielały światło od ciemności (18b)

Według tego modelu w centrum struktury dnia czwartego znajduje się wzmianka o stworzeniu dwóch ciał niebieskich, których zadaniem jest rządzenie dniem i nocą.

Jak zauważa Vogels, model ten, wskazując na paralelę między 14b („aby wyznaczały pory roku, dni i lata”) i 18a („aby rządziły dniem i nocą”) wydaje się być nieco „naciągany”. On sam, podążając za Beauchamp, proponuje model nieco mniej regularny ${ }^{24}$ :

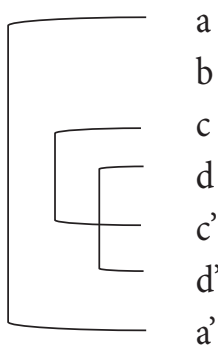

aby oddzielać dzień od nocy (14a)

aby wyznaczały pory roku, dni i lata (14b)

aby świeciły nad ziemią (15)

aby rządziło dniem..., aby rządziło nocą (16)

aby świeciły nad ziemią (17)

aby rządzily dniem i nocą (18a)

aby oddzielały światło od ciemności (18b)

Powyższy model struktury wskazuje siedem funkcji ciał niebieskich, nawiązując w ten sposób do schematu liczbowego, który został ewidentnie podkreślony w kapłańskim opowiadaniu o stworzeniu. Uwypukla również fakt powtórzenia trzech funkcji z pierwszej części perykopy (faza planowania), w nieco zmodyfikowanej kolejności, w części drugiej (faza instalowania). Nieregularność ta wydaje się wskazywać, że powtórzenie to służy raczej uzyskaniu pewnego efektu retorycznego, niż budowaniu idealnie symetrycznej kompozycji ${ }^{25}$. Jednocześnie, jak zauważa

23 Rzeczownik מועדים zostanie szerzej omówiony w dalszej części artykułu. Do tego czasu posługiwać się będziemy wyrażeniem „pory roku” zaproponowanym w tłumaczeniu BT.

24 Zob. Vogels, „The Cultic”, 172.

25 Zob. Pawłowski, Opowiadanie, 317. 
Beauchamp ${ }^{26}$, a za nim Vogels ${ }^{27}$, jedyną funkcją, która nie znajduje w opowiadaniu paraleli, jest wyznaczanie „pór roku, dni i lat”. Dla części egzegetów fakt ten stanowi jeszcze jeden dowód na to, że element ten jest poźniejszym dodatkiem redakcyjnym. $Z$ drugiej strony nie brak egzegetów, którzy sądzą, że tego typu nieregularności i asymetrie odgrywają w tekście istotną funkcję ${ }^{28}$. Stanowią bowiem element zaskoczenia - uwypuklają element „asymetryczny” i koncentrują na nim uwagę czytelnikaa'. W tym wypadku w centrum uwagi staje funkcja wyznaczania „pór roku, dni i lat”. Co ciekawe, o ile pozostałe funkcje ciał niebieskich wydają się być związane przede wszystkim z rzeczywistością dnia i nocy, światła i ciemności, których dotyczy przede wszystkim pierwszy dzień stworzenia, funkcja wskazywania „pór roku, dni i lat” okazuje się być specyficznym elementem dnia czwartego. To ona stanie się przedmiotem naszego szczególnego zainteresowania w drugiej części niniejszego artykułu.

\section{Stworzenie i specyficzna funkcja ciał niebieskich w $\operatorname{Rdz} 1,14$}

Analiza przeprowadzona w pierwszej części artykułu sugeruje nam wyjątkowe miejsce, jakie opis stworzenia ciał niebieskich zajmuje w strukturze Heptameronu. Wskazuje także na funkcję wyznaczania "pór roku, dni i lat” jako istotny i charakterystyczny cel, dla którego ciała niebieskie zostały stworzone. Kontynuując krytyczną refleksję nad tym aspektem stworzenia ciał niebieskich, pragniemy zwrócić uwagę na elementy polemiczne w opisie redaktora kapłańskiego (2.1), a następnie przyjrzeć się uważniej roli ciał niebieskich w temporalnej organizacji kosmosu (2.2).

\subsection{Polemiczny wymiar opowiadania o stworzeniu ciał niebieskich}

Owocem stwórczej aktywności Boga w czwartym dniu są „ciała niebieskie świecące na sklepieniu nieba" (Rdz 1,14). Fakt, że są one stworzone, że ich stworzenie według koncepcji redaktora kapłańskiego przypada na dzień czwarty ${ }^{30}$, a wreszcie, zaskakująca nieco, idea rozdzielenia stworzenia światła w dniu pierwszym i stworzenia „ciał świecących na sklepieniu nieba" w dniu czwartym, wydają się zawierać jasny przekaz na temat miejsca ciał niebieskich w kapłańskiej wizji stworzonego świata. Jak zauważa Claus Westermann, „słońce i księżyc były bóstwami w świecie, w którym Izrael żył, i to bóstwami mającymi pierwszorzędne znaczenie" ${ }^{\prime \prime}$. Kompozycja redaktora

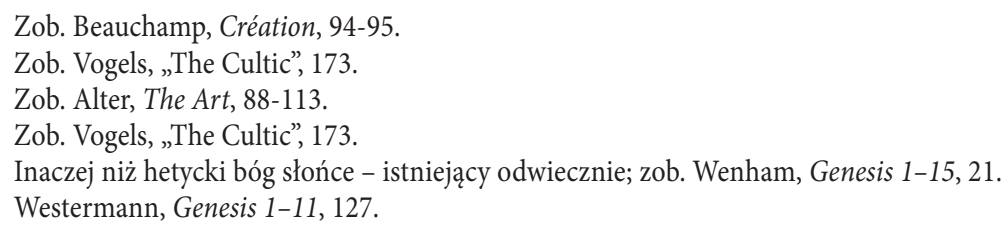


kapłańskiego, w której jest miejsce na jednego tylko Boga - Stwórcę nieba i ziemi, a czczone przez sąsiednie narody jako bóstwa, słońce, księżyc i gwiazdy są niczym innym, jak tylko ciałami świecącymi na sklepieniu nieba, uczynionymi na dodatek na czwartym etapie dzieła stworzenia, staje się - jeśli nie wyzwaniem czy otwartą polemiką - to przynajmniej „zdaniem odrębnym” (votum separatum) na mapie teologicznych idei starożytnego Bliskiego Wschodu. Przesłanie redaktora kapłańskiego wydaje się być dodatkowo wzmocnione przez fakt, że ciała niebieskie, o których mowa w Rdz 1,14-19, pozostają do pewnego stopnia „anonimowe”. Jak wspomnieliśmy wyżej, w kadrze, który opowiada o ich stworzeniu, brak jest elementu nadawania przez Boga imienia ${ }^{32}$. Fakt ten wzmacnia być może argumenty tych, którzy zaliczają dzień czwarty do drugiej fazy dzieła stworzenia. O ile bowiem Bóg nadaje imiona elementom kosmosu uczynionym w ciągu pierwszych trzech dni, o tyle w przypadku drugiej triady czynność ta nie pojawia się w opisie stwórczej aktywności Boga. Warto zwrócić uwagę, że do tej pory swoje imię otrzymały wszystkie elementy wspomnianej wyżej „fazy kosmologicznej”: światło, ciemność, sklepienie, zbiorowisko wód, sucha powierzchnia. Tymczasem, należące niewątpliwie do niej tematycznie, ciała niebieskie pozostaną bezimienne w opowiadaniu redaktora kapłańskiego. Jego determinacja w unikaniu nazw „słońce” i „księżyc” widoczna jest w już w wersecie 16, gdzie ucieka się on do bardzo ogólnych terminów, a nawet nieco dziwacznych konstrukcji. Mówi najpierw o dwóch ciałach większych (המארת הגדלים - dosł. „duże ciała świecące"), a następnie o ciele dużym (המאור הגדל) i małym (המאור הקטן). Wydaje się, że przyczyn tej determinacji upatrywać należy w tym, że obie nazwy specyficzne: שמרל (משר („słońce”) i ירח („księżyc”), funkcjonowały nie tylko jako imiona ciał niebieskich, ale również jako imiona własne czczonych pośród Semitów bóstw ${ }^{33}$.

Elementem języka polemicznego może być również kolejność, w jakiej redaktor kapłański wspomina ciała niebieskie stworzone w dniu czwartym: słońce, księżyc, gwiazdy. W mezopotamskim opowiadaniu Enûma Eliš pierwszeństwo przypada gwiazdom, które zwycięski Marduk osadza na sklepieniu nieba, „by żadna nie popełniła błędu, nie zlekceważyła zadania" ${ }^{34}$. Dopiero potem przystępuje do organizacji kalendarza, określa położenie planet, wreszcie ustala zasady funkcjonowania księżyca i słońca. Jak zauważa Victor P. Hamilton, w Enûma Eliš brak jest jednoznacznej wzmianki o stworzeniu ciał niebieskich, „ponieważ są one bogami” - zostają jedynie umieszczone na przeznaczonych im kosmicznych miejscach ${ }^{35}$.

32 Choć psalmista nie mą wątpliwości, kiedy woła: „On liczbę gwiazd oznacza, wszystkie je woła po imieniu” (Ps 147,4).

33 Zob. Hamilton, Genesis 1-17, 127. Echem kultu słońca i księżyca mogą być nazwy geograficzne na teranie Izraela, takie jak: Bet Szemesz („dom/przybytek słońca”), En Szemesz („źródło słońca”), Ir Szemesz („miasto słońca”) czy Jerycho, a także imiona własne, jak choćby Szemeszezer („łłońce jest pomocą”). Zob. DCH VIII, 489.

34 tyczkowska (tł.), „Enūma Eliš", 36.

35 Hamilton, Genesis 1-17, 128. 
Fakt, że słońce, księżyc i gwiazdy przedstawione są jako „ciała świecące” stworzone przez Boga w czasie i umieszczone na sklepieniu nieba, nie oznacza jednak ich całkowitej degradacji. Są nie tylko dziełem Stwórcy, ale również stworzeniami, którym powierzone zostały specjalne zadania. Na ich wyjątkowość pośród zastępów stworzeń, jak mogliśmy się przekonać w pierwszej części artykułu, wydaje się wskazywać pozycja dnia czwartego w kompozycji Heptameronu oraz struktura opisu stworzenia ciał niebieskich. O tej wyjątkowości wydaje się również świadczyć nazwa, jakiej na ich określenie używa redaktor kapłański, a także specyficzny zestaw funkcji powierzonych ciałom niebieskim.

$\mathrm{Na}$ określenie słońca, księżyca i gwiazd redaktor Heptameronu używa hebrajskiego terminu מארת ,מאור , מאור , kriatła”, „ciała świecące”, „lampy”36. Rzeczownicy w sobie rdzeń אור , „światło”, „świecić”, „dawać, rzucać światło”, występuje 19 razy w Biblii Hebrajskiej, z czego aż pięciokrotnie w Rdz 1,14-19 (ww. 14, 15, 16 x 3). Znaczenie podobne do tego $\mathrm{z} R \mathrm{Rz} 1$ odnajdujemy wdwóch tekstach biblijnych.

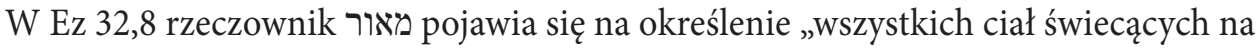
niebie" (כל־מאורי אור בשמים). Z kolei w Ps 74,16 rzeczownik מאור pojawia się w parze

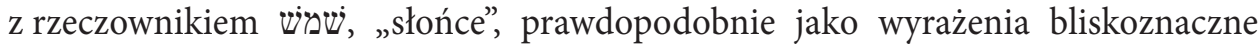

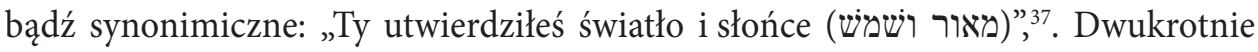
rzeczownik מאור pojawia się w Biblii Hebrajskiej w znaczeniu metaforycznym, na określenie „światła oblicza” (Ps 90,8) lub „rozświetlonych oczu” (Prz 15,30). Wszystkie pozostałe wystąpienia dotyczą Pięcioksięgu, gdzie - poza Rdz 1 - termin ten odnosi się do lampy czy też świecznika świecących w przybytku (zob. Wj 25,6; 27,20; $35,8.14 .28$; 39,37; Kpł 24,2; Lb 4,9.16 - zawsze w liczbie pojedynczej!). Fakt ten, być może, rzuca światło na liturgiczny wymiar kapłańskiego opowiadania o stworzeniu. Słońce, księżyc oraz gwiazdy nie są jedynie ozdobami zawieszonymi na sklepieniu nieba, nie są zwykłym oświetleniem stworzonego świata. Jak zauważa Vogels, pełnią one raczej rolę świętych lamp czy też świeczników umieszczonych w świątyni kosmosu $^{38}$.

\section{2. „Aby odmierzały czas...". Rola ciał niebieskich w temporalnej organizacji kosmosu}

Jak mogliśmy dostrzec analizując strukturę perykop Rdz 1,14-19, pośród funkcji powierzonych ciałom niebieskim na szczególną uwagę wydaje się zasługiwać wskazywanie „pór roku, dni i lat” (14b). Ten fragment wersetu 14 zbudowany jest z formy

\footnotetext{
36 DCH V, 116-117.

37 Biblia Paulistów (Pismo Święte Starego i Nowego Testamentu. Najnowszy przekład z języków oryginalnych $z$ komentarzem [Częstochowa: Święty Paweł 2008]), być może pragnąc zachować paralelizm z pierwszą częścią wersetu, tłumaczy מאור w Ps 74,16, jako „księżyc”: „Twój jest dzień i noc jest Twoja, Ty utwierdziłeś słońce i księżyc".

38 Zob. Vogels, „The Cultic”, 175.
} 
odwróconego perfectum czasownika ו ו ו + Qal Perf. 3 m pl.) oraz czterech rzeczowników w liczbie mnogiej: „znaki”, „pory roku”, „dni” i „lata”, przy czym trzy pierwsze poprzedzone są przyimkiem ל wskazującym - jak wspomnieliśmy - cel, kierunek lub funkcję rzeczownika. Przyimka tego brak przy rzeczowniku oznaczającym „lata” (והיו לאתת ולמועדים ולימים ושנים) 39. Tak sformułowane zdanie stwarza dwa problemy: jeden o charakterze syntaktycznym, drugi - semantycznym. Problem składni dotyczy relacji między czterema rzeczownikami. Większość egzegetów uznaje, że brak przyimka ל przed rzeczownikiem שנים wskazuje, że „dni” i „lata” tworzą pewną całość („dni i lata”), do której odnosi się przyimek umieszczony przed słowem „dni”. Nieco bardziej skomplikowany wydaje się związek między rzeczownikiem „znaki” (אתת) i pozostałymi rzeczownikami. Można przyjąć, że rzeczownik מועדים מוז („worzy z następującym po nim rzeczownikiem roku”) hendiadys: „niech będą znakami pór roku” lub „niech wyznaczają pory roku” ${ }^{40}$. Można również uznać, że rzeczownik „znaki” odnosi się do wszystkich występujących po nim słów, które tworzą dwie grupy: „[ciała niebieskie] niech służą jako znaki, [tzn. niech wskazują] zarówno pory roku, jak również dni i lata”" ${ }^{41}$. Można wreszcie uznać, że słowo אתת oznacza jakieś niezwykłe zjawisko na niebie (np. kometę, zaćmienie czy choćby tęczę, która w Rdz 9,13.17 również określona jest jako „znak”) lub omen (zob. Iz 38,7). Jeśli przyjmiemy to znaczenie, ciała niebieskie mają służyć jako „niezwykłe znaki, lub jako pory roku, lub też jako dni i lata”. W takim wypadku niezwykłe znaki, obok pór roku oraz dni i lat, tworzą trzy kategorie zjawisk, regulowanych przez funkcjonowanie ciał niebieskich. Zdaniem Wenhama, choć brak jest ostatecznych argumentów, które pozwoliłby wybrać jedną z tych możliwości, wykluczając pozostałe, to jednak najprostszą (czy zatem najbardziej prawdopodobną?) okazuje się kategoria druga ${ }^{42}$. Wydaje się, że na ewentualny wybór którejś z opcji wpływa znaczenie rzeczownika אתת, za którym się opowiemy. Obecność - pozornie zbędnego - spójnika 1 przed rzeczownikiem „pory roku” może sugerować pewien nacisk: Oto zadaniem ciał niebieskich jest funkcjonowanie jako znak wskazujący zarówno מועדים („pory roku”), jak również dni i lata (ימים וֹשנים). Może on mieć również znaczenie eksplikatywne.

Obok problematycznej składni wersetu 14b zasygnalizowany został również problem semantyczny. Pewien jego aspekt mogliśmy dostrzec, analizując relacje między poszczególnymi rzeczownikami występującymi w zdaniu. Trudno w tak krótkim opracowaniu dedykować więcej miejsca na omówienie rzeczowników יום („dzień”) שנה i („rok”). Wystarczy jedynie wspomnieć, że terminy te wydają się wyznaczać

39 Warto zwrócić uwagę na wersję Septuaginty, Peszittę oraz teksty z Qumran (4Q10 [4QGen]), które wskazują na wariant językowy ולשנים. Zob. BHQ, 4. Por. Giuntoli, Genesi 1,1-11,26, 81.

40 Zob. Skinner, Genesis, 25; Speiser, Genesis, 6; Sarna, Genesis, 9.

41 Zob. Westermann, Genesis 1-11, 130.

42 Zob. Wenham, Genesis 1-15, 23.

43 Zob. Vogels, „The Cultic”, 168. 
naturalne podziały czasu w życiu człowieka, które regulowane są przez cykliczną przemianę światła i ciemności, wskazującą dzień, oraz cykl przemian pogody (np. następujące po sobie pory sucha i deszczowa, znajdujące odbicie w cyklu wegetacji), który wyznacza rok ${ }^{44}$. Podobna jednak powściągliwość w przypadku rzeczowników אות („znak”) oraz („pora roku”, „ustalony/wyznaczony czas”) naraziłaby nas na pominięcie istotnego elementu temporalnej organizacji stworzonego świata.

Spośród czterech terminów użytych w Rdz 1,14b, rzeczownik אות wydaje się tym, który najmniej związany jest z ideą czasu. Jego podstawowe znaczenie to „znak”, „symbol”, „dowód”, „zapowiedź”45. Franz J. Helfmeyer, który za Hermannem Gunkelem określa אות jako „przedmiot, zjawisko, zdarzenie, dzięki któremu osoba ma rozpoznać, dowiedzieć się, zapamiętać lub dostrzec wiarygodność czegoś”, podkreśla przede wszystkim funkcjonalny wymiar tego pojęcia i jego znaczenie komunikacyjne ${ }^{46}$. Znak sugeruje znaczenie, które wykracza poza zewnętrzną formę znaku; komunikuje przesłanie, które wymaga interpretacji, zrozumienia. W tym sensie אתת („znaki”) w Rdz 1,14b mogą wskazywać na rzeczywistość czasu wyrażoną terminami „pory roku” oraz „dni i lata”. Nie brak jednak badaczy, którzy zwracają uwagę, że w pewnych okolicznościach אות staje „poliwalentnym określeniem o charakterze kosmologicznym”, które łączy w sobie ideę „niezwykłych zjawisk niebieskich" $\mathrm{z}$ ideą wzorca czy reguły odnoszącej się do temporalnego wymiaru rzeczywistości. Bruce K. Gardner określa אות jako „słowo o znaczeniu kalendarzowym w tradycji żydowskiej" ${ }^{47}$. Jako ilustrację swego twierdzenia Gardner przytacza oryginalną interpretację Ps 74. Jego zdaniem widoczny w tym psalmie kontekst kultyczny oraz nawiązania do poskromienia pierwotnego chaosu, do dzieła stworzenia rozumianego jako proces rozdzielania i ustanawiania granic, a także do wyjścia z niewoli egipskiej, sugerują temporalne znaczenie rzeczownika אות w Ps 74,4.9. Jak pisze:

to be without אתת was to be bereft of their national and sacred order, and robbed of those distinctives which had defined them as a people under God. Their both symbolised and determined the correct times of approach to God, as it were validating the space given over to worship in Jerusalem by setting the temporal terms for the relationship with Him who is beyond time and space ${ }^{48}$.

W tym kontekście badacze przywołują często qumrański dokument 4QOtot, w którym אות oznacza specyficzny układ słońca i księżyca w momencie ich stwo-

\footnotetext{
44 Zagadnienie „dnia” w kapłańskim opowiadaniu o stworzeniu zostało szerzej omówione w Napora, „Czas w kapłańskim opowiadaniu o stworzeniu".

Zob. BDB, 16-17.

Helfmeyer, "אile ôth", 170.

Gardner, The Genesis Calendar, 71.

Gardner, The Genesis Calendar, 76.
} 
rzenia; układ, który powtarza się w określonych odstępach czasu. Jak wyjaśnia Eibert J. C. Tigchelaar, chodzi czy to o pełnię, czy może raczej nów księżyca w czasie wiosennego zrównania dnia i nocy ${ }^{49}$. Zjawisko to służyło być może interkalacji, tzn. dokonywanemu cyklicznie uzgodnieniu 364-dniowego kalendarza wspólnoty qumrańskiej z cyklem słonecznym i księżycowym poprzez dodanie określonej liczby dni.

Analizując znaczenie אתת w Rdz 1,14b, warto również przywołać późne teksty biblijne oraz przykłady literatury apokryficznej, w których pojawiają się świadectwa interpretacji kapłańskiego opowiadania o stworzeniu. W Syr 43,6-10 czytamy:

${ }^{6}$ Księżyc też świeci zawsze w swojej porze, aby ustalać czas i być wiecznym znakiem. Księżyc wyznacza dni świąt; jest to źródło światła, które się zmniejsza, osiągnąwszy pełnię. ${ }^{8}$ Miesiąc od niego ma swoje imię. Zwiększając się dziwnie wśród odmian, jest latarnią obozową wojska na wysokościach, świecącą na sklepieniu niebieskim. ${ }^{9}$ Wspaniałość gwiazd jest pięknem nieba, błyszczącą ozdobą na wysokościach Pana. ${ }^{10} \mathrm{Na}$ polecenie Świętego trzymają się Jego wyroku i nie nużą się odbywaniem swych straży. ${ }^{50}$

Warto zwrócić uwagę, że księżyc nazywany jest w tekście „wiecznym znakiem” (אות עולם). Co ciekawe, to właśnie księżycowi Syrach przypisuje funkcję panowania

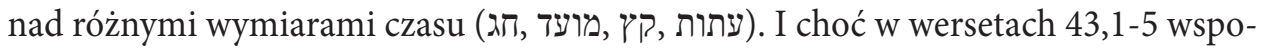
mina on również słońce, to jednak milczy na temat jego roli w kontekście panowania nada czasem.

Odwrotną sytuację odnajdujemy w Księdze Jubileuszów. W tekście będącym parafrazą biblijnego opowiadania o stworzeniu czytamy:

Czwartego dnia uczynił słońce, księżyc i gwiazdy. Umieścił je na firmamencie niebieskim, tak by rzucały światło nad całą ziemią i rządziły dniem i nocą, oddzielając światło i ciemność. I Pan ustanowił słońce jako wielki znak nad ziemią dla ustalenia poszczególnych dni, tygodni, miesięcy, świąt, lat, siedmioleci, jubileuszy i wszystkich okresów szczególnych w roku. I ono oddziela światło od ciemności, tak aby wszystko, co kiełkuje i wzrasta na ziemi, mogło dobrze się rozwijać. Te trzy dzieła uczynił dnia czwartego $(J u b 2,8-10)^{51}$.

Tekst wymienia ciała niebieskie, o których wspomina Rdz 1,14: słońce, księżyc i gwiazdy. Również w Księdze Jubileuszów pełnią one funkcje podobne do tych,

49 Zob. Tigchelaar, „Lights”, 46-47.

50 W manuskrypcie Księgi Mądrości Syracha odnalezionym w Masadzie, zrekonstruowanym na podstawie

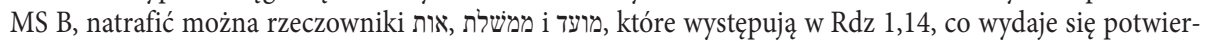
dzać relację między obydwoma tekstami. Zob. Tigchelaar, „Lights”, 37.

51 Kondracki (tł.), „Księga Jubileuszów”, 265. 
o których wspomina Księga Rodzaju: świecą nad ziemią, rządzą dniem i noc oraz oddzielają światło od ciemności. Tym razem jednak to słońce nazwane jest „wielkim znakiem”. I to ono (a nie księżyc czy gwiazdy!) wskazuje poszczególne okresy czasu. Warto zwrócić uwagę, że autor Księgi Jubileuszów rozbudowuje listę czasów wyznaczanych przez słońce, wspominając „dni, tygodnie, miesiące, święta, lata, siedmiolecia, jubileusze oraz wszystkie okresy szczególne w ciągu roku”.

Wzmiankę o znakach gwiazd, słońca i księżyca zawiera również Jub 12,16-17:

Dnia pierwszego w siódmym miesiącu, roku piątego w szóstym tygodniu Abram siedział nocą i obserwował gwiazdy od wieczora do rana, by w ten sposób rozpoznać, jakie ilości deszczu miał przynieść nadchodzący rok. Siedział on samotnie i obserwował. Wtedy przyszły mu na myśl (do serca) takie słowa: Wszystkie znaki gwiazd i wszystkie znaki słońca i księżyca są w ręku Pana. Dlaczego więc ja poszukuję ?5 $^{52}$.

W tym tekście „znaki gwiazd, księżyca i słońca” wydają się być pozbawione konotacji temporalnej. Stanowią raczej omen, który wpływa w jakiś sposób na życie człowieka, a nawet wydaje się mieć nad nim pewną władzę. Owocem całonocnej refleksji wpatrzonego w znaki nieba Abrama jest jednak stwierdzenie, które wydaje się być w pełni zgodne z Rdz 1,14-19. To Bóg jest Stwórcą ciał niebieskich i tylko z Jego woli mogą one pełnić funkcję znaku.

Drugim słowem, które nastręcza trudności tłumaczom w Rdz 1,14b jest rzeczownik מועד (מועד (1.p.). Nawet odwołując się jedynie do polskich wydań tekstu biblijnego, odnajdujemy kilka możliwych wariantów tłumaczenia tego słowa, które bywa oddawane jako: „pory roku” (Biblia Tysiąclecia), „święta” (Biblia Poznańska, Biblia Paulistów), „czasy” (Biblia J. Wujka, Biblia Ekumeniczna) czy też „pory” (Biblia Warszawska). Rzeczownik מועד kryje w sobie rdzeń יעד. W koniugacjach Qal i Hiphil czasownik יעד przyjmuje znaczenie „ustalić”, „wyznaczyć”, „zebrać”, „ustalić spotkanie" (1 Sm 21,3; 2 Sm 20,5; Jr 47,7; 49,19; 50,44). To ostatnie obecne jest również w koniugacji Nifal (np. Ps 48,5; Ps 3,3). Jak widać, znaczenia te koncentrują się wokół dwóch głównych idei: $z$ jednej strony chodzi o spotkanie, zebranie, $\mathrm{z}$ drugiej - o wydarzenie o charakterze nie tyle spontanicznym czy przypadkowym, co raczej zaaranżowanym, umówionym, zaplanowanym. Obydwie te idee wydają się determinować znaczenie rzeczownika מועד, który pojawia się 223 razy kartach Biblii Hebrajskiej ${ }^{53}$. Aż 146 razy (co oznacza ponad 65 procent wszystkich wystąpień) מועד występuje z rzeczownikiem אהל w wהל מועד namiot spotkania”. W Pięcioksięgu rzeczownik מועד pojawia się dokładnie 160 razy (tzn. blisko 72 procent wszystkich wystąpień), z czego 135 razy w odniesieniu do namiotu spotkania. Jak zauważa Vogels, spośród pozostałych 25 wystąpień przypadających na Torę, מועד

52 Kondracki (tł.), „Księga Jubileuszów”, 286.

53 Na podstawie Accordance Bible Software (wersja 13.0.5). 
kilkakrotnie odnosi się do określonego i wyznaczonego przez Boga czasu. Trzykrotnie chodzi o narodziny Izaaka ( $\mathrm{Rdz} 17,21 ; 18,21 ; 21,2)$, jeden raz o plagi egipskie (Wj 9,3). W pozostałych przypadkach rzeczownik odnosi się do ustalonego czasu świąt liturgicznych, zwłaszcza do święta Paschy (Wj 13,10; Lb 9,2.3.7.13) i Przaśników (Wj 23,15; 34,18), czy też wyznaczonego „roku darowania długów” (Pwt 31,10). W niektórych tekstach rzeczownik ten oznacza nie tyle czas określonych świąt, co raczej samo święto ${ }^{54}$. Na przykład Kpł 23 rozpoczyna stwierdzenie: „Oto czasy święte Pana” lub raczej „oto święta Pana” (אלה מועדי יהוה; Kpł 23,2.4), po których następuje wykaz obejmujący szabat, Paschę, Święto Przaśników, Święto Tygodni, Sukkot. Zakończenie rozdziału na zasadzie inkluzji przywołuje dwukrotnie stwierdzenie „święta Pana” (Kpł 23,37.44). Podobną klamrę, zawierającą wzmiankę o świętach, odnaleźć można w Lb 28,2 i 29,39. Obejmuje ona rozdziały zawierające instrukcje dotyczące ofiar, które Izraelici winni składać w czasie świąt. W Lb 10,10 מועדים pojawiają się obok takich celebracji liturgicznych, jak „,dni radosne”55, dni nowiu, w kontekście ofiar całopalnych i biesiadnych. Z kolei w Lb 15,3 rzeczownik wydaje się odnosić ogólnie do świąt liturgicznych (Lb 15,3).

$\mathrm{W}$ tekstach tradycji deuteronomistycznej oraz $\mathrm{w}$ tekstach prorockich znaczenie słowa wydaje się odpowiadać temu, które widzieliśmy w Pięcioksięgu. Rzeczownik מועד pojawia się w kontekście ustalonych czasów (np. czas ustalonych spotkań w $1 \mathrm{Sm} \mathrm{13,8,} \mathrm{czas} \mathrm{narodzin} \mathrm{w} 2 \mathrm{Krl}$ 4,16-17, czas spotkania Boga ze swoim ludem w Oz 12,10) czy też miejsc (świątynia w Lm 2,6, niebo w Iz 14,13, Szeol w Hi 30,23). W wielu tekstach prorockich rzeczownik ten powraca w znaczeniu ,święto" (Iz 33,20; Ez 36,38; 46,9.11); w wielu innych מועד zostało użyte w kontekście celebracji liturgicznych, razem z takimi określeniami jak „uroczystości”, „święta nowiu” czy „szabaty". Bywa również używany jako paralela rzeczownika na określenie trzech dorocznych świąt pielgrzymkowych (Wj 23,14-17). Jedynie w dwóch przypadkach, jak notuje Vogels, מועד pojawia się w odniesieniu do określonego czasu w kontekście natury. Są to wzmianki o czasie migracji ptaków (Jr 8,7) oraz o porze żniw $(\mathrm{Oz} 2,11)$. I choć trzeba mieć świadomość, że naturalny rytm pór roku, i związany z nim cykl wegetacji, miał ogromny wpływ na porządek świąt liturgicznych określony na kartach Biblii Hebrajskiej, to jednak właśnie ów porządek „ponad-naturalny” wydaje się być zaznaczony przez rzeczownik מועדים.

Częstotliwość, z jaką rzeczownik ten pojawia się w kontekście liturgicznym, daje podstawy, by מועדים w Rdz 1,14b rozumieć jako odniesienie do kalendarza o charakterze liturgicznym, do liturgicznych świąt i uroczystości wyznaczanych w relacji

54 Vogels, „The Cultic”, 164.

55 Sygnał grany na trąbach wspomniany jest w Biblii w kontekście wielu radosnych celebracji: koronacji (2 Krl 11,14), instalacji arki w namiocie „rozpiętym” przez Dawida (1 Krn 16,6), dedykacji świątyni Salomona (2 Krn 5,12-13), oczyszczenia świątyni za czasów Ezechiasza (2 Krn 29,27), położenia fundamentów drugiej świątyni (Ez 3,10). Zob. Milgrom, Numbers, 73. 
do ciał niebieskich, zwłaszcza faz księżyca ${ }^{56}$. W tym kontekście tłumaczenie מועדים jako „święta” wydaje się znacznie trafniejsze niż - odwołujące się raczej do funkcjonowania natury - określenie „pory roku”. Oczywiście warto zastanowić się, dlaczego redaktor kapłański nie użył w Rdz 1,14b innego słowa, choćby precyzyjnego i jednoznacznego określenia גת, dlaczego uciekł od pewnej dosłowności, posługując się nieco bardziej ogólnym terminem מועד? Analogiczny zabieg znajdujemy, jak się wydaje, w Rdz 2,1-3 w odniesieniu do szabatu, gdzie, jak stwierdza Lemański, „zamiast mówić wprost o szabacie, wspomina się raczej o przestrzeni czasowej przygotowanej - w ramach porządku stworzenia - na pojawienie się szabatu"s7. Być może jest to wskazówka, że zamysłem redaktora kapłańskiego nie jest wcale prezentacja precyzyjnej etiologii poszczególnych świąt i uroczystości, lecz - przywołując określenie Lemańskiego - „stworzenie pewnej przestrzeni czasowej”, która zostanie zapełniona, kiedy ukonstytuowany zostanie ostatecznie cykl świąt.

W określeniach „czasy święte/święta” (מועדים), „dni i lata” (ימים ושנים) badacze widzą niekiedy aluzję do dwóch wymiarów odmierzania czasu: religijnego (liturgicznego) i świeckiego. Jak zauważa David J. Rudolph, wspomnienie o znakach i świętach liturgicznych przed wzmianką o podziale na dni i lata sugerować może przewagę kalendarza religijnego nad świeckim. Może sugerować, że ciała niebieskie stworzone zostały najpierw, aby wyznaczać święty czas spotkania Boga z człowiekiem, a dopiero później jako element miary czasu ${ }^{58}$. Być może nie ma jednak konieczności tak radykalnego przeciwstawiania sobie obu wymiarów czasu. Obydwa tworzą przecież wspólnie kalendarz, który zostaje zainaugurowany właśnie w czwartym dniu stworzenia. O ile kosmiczny zegar wydaje się odmierzać czas począwszy od dnia pierwszego, o tyle w dniu czwartym odmierzanie czasu rozpoczyna kalendarz kosmiczny. W tym sensie kapłańskie opowiadanie o stworzeniu zawiera idę podwójnego początku! ${ }^{59}$ Dla Annie Jaubert kapłańskie opowiadanie o stworzeniu staje się teoretyczną bazą dla kalendarza słonecznego, liczącego 364 dni (dokładnie 52 tygodnie), znanego z Księgi Jubileuszów, według którego święta przypadały w stałe dni tygodnia. W kalendarzu tym to właśnie dzień czwarty okazuje się wyróżniony ze względu na przypadające w nim święta: Nowy Rok, Paschę oraz Święto Namiotów ${ }^{60}$. Z kolei Gardner w „,zrównoważonej opozycji” między dniem pierwszym i czwartym, wyznaczającymi dwa początki, widzi teoretyczne źródła dwóch systemów kalendarzowych zarysowanych przez redaktora kapłańskiego: księżycowo-słonecznego i liczącego 364 dni kalendarza słonecznego ${ }^{61}$. Nie negując faktu, że realnie istniejące metody rachuby czasu (a nawet pewne kontrowersje z tym związane!) mogły znaleźć

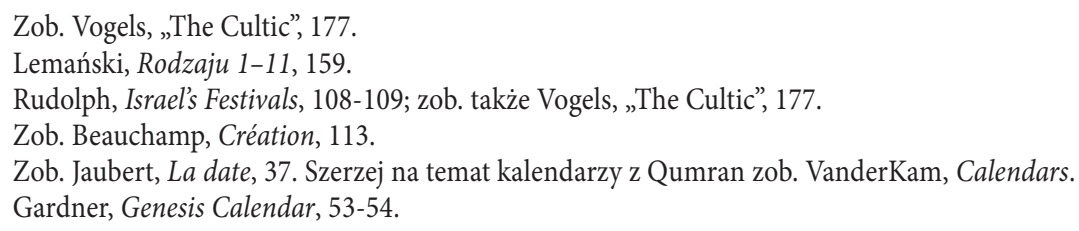


swe odbicie w opowiadaniu o stworzeniu, wydaje się słusznym przyjąć za Zdzisławem Pawłowskim, że

sens porządku czasowego w Genesis 1,1-2,3 nie daje się zamknąć w granicach chronometrii czy chronografii, choć jakieś elementy pojmowania czasu z obydwu tych zakresów są w nim obecne. Nie rozwija także chronologii, aczkolwiek ją umożliwia, ustanawiając jej punkt początkowy. Wydaje się, że najbliższe jest rozumienie wypracowane przez chronozofię, bo właśnie pojęcie struktury wyrażone w schemacie siedmiu dni odgrywa w nim decydującą rolę $e^{62}$.

W strukturze tej, jak mogliśmy się przekonać, dzień czwarty zajmuje z całą pewnością szczególne miejsce, stanowiąc rzeczywiście le clé de voûte - „klucz sklepienia” tworzonego przez dzień pierwszy, czwarty i siódmy, wyznaczające temporalną strukturę stworzonego świata.

\section{Zakończenie}

W ten sposób, wychodząc od spojrzenia na miejsce dnia czwartego w kapłańskim opowiadaniu zawartym w Rdz 1,1-2,4a, poprzez analizę struktury kadru relacjonującego stworzenie ciał niebieskich, badając wreszcie wybrane elementy jego tematycznej zawartości, docieramy do momentu, w którym odkrywamy istotę stwórczej aktywności Boga w czwartym dniu stworzenia. Z całą pewnością nie wyczerpuje jej przestrzenne zagospodarowanie sklepienia niebieskiego, wyznaczanie trajektorii planet, ustalanie pozycji słońca i księżyca oraz ich wzajemnej zależności. Prawdą jest, że w opisie dnia czwartego - być może wyraźniej niż w którymkolwiek z pozostałych dni Heptameronu - wyczuć można pewną nutę polemiczną w stosunku do kultów i wierzeń, w których słońce, księżyc i gwiazdy reprezentowały istoty boskie i wpływały bezpośrednio na ludzkie losy. Niewykluczone, że usłyszeć w nim można echo polemiki pomiędzy zwolennikami kalendarza opartego na cyklu słońca ze zwolennikami kalendarza regulującego ludzkie życie i aktywność na podstawie cyklów księżyca. Być może tekst stanowi świadectwo kroku w stronę mądrego kompromisu, który zaowocował kalendarzem luni-solarnym. Ale być może chodzi o coś jeszcze... Być może chodzi o jeszcze jeden element opowieści o Bogu, „do którego należy dzień i noc, który światło i słońce utwierdził, który obmyślił lato i zimę i ustanowił wszystkie granice ziemi” (zob. Ps 74,16-17); opowieści o Bogu, który stworzył świat rozdzielając... Chodzi raczej o ukazanie, że od samego początku w zamyśle Stwórcy czas jest zróżnicowany, określany nie tylko równym rytmem przemiany dnia i nocy, od-

62 Pawłowski, „Antropologiczne”, 169. 
mierzany nie tylko równym pulsem mijających lat, ale taktowany przede wszystkim regularnym cyklem świąt i uroczystości, czasów uroczystych zgromadzeń, czasów niezwykłej komunikacji, nawet intymności z Bogiem... Czasów, których schemat zapisał Bóg na partyturze nieba nutami ciał niebieskich w czwartym dniu stworzenia.

\section{Bibliografia}

Alter, R., The Art of Biblical Narrative (New York: Basic Books 1981).

Beauchamp, P., Création et séparation. Étude exégétique du chapitre premier de la Genèse (Lectio Divina 201; Paris: Cerf 2005).

Brown, F. - Driver, S.R. - Briggs, C.A., A Hebrew and English Lexicon of the Old Testament with Appendix Containing the Biblical Aramaic (Peabody, MA: Hendrickson 1979) (= BDB).

Clines, D.J.A., The Dictionary of Classical Hebrew (Sheffield: Sheffield Academic Press 1993-2016) I-IX (= DCH).

Dziadosz, D., Tak było na początku. Izrael opowiada swoje dzieje (Przemyśl: Wydawnictwo Archidiecezji Przemyskiej 2011).

Gardner, B.K., The Genesis Calendar. The Synchronistic Tradition in Genesis 1-11 (Lanham, MD: United Press of America 2001).

Gesenius, W. - Kautzsch, E., Gesenius' Hebrew Grammar (tł. A.E. Cowley) (Oxford: Oxford University Press 1910) (= GKC).

Giuntoli, F., Genesi 1,1-11,26. Introduzione, traduzione e commento (Nuova versione della Bibbia dai testi antichi 1/1; Cinisello Balsamo: San Paolo 2013).

Gunkel, H., Genesis (Handkommentar Zum Alten Testament 1; Göttingen: Vandenhoeck \& Ruprecht 1901).

Hamilton, V.P., The Book of Genesis. Chapters 1-17 (New International Commentary on the Old Testament; Grand Rapids, MI: Eerdmans 1990).

Helfmeyer, F.J., „אוֹ ôth", Theological Dictionary of the Old Testament (red. G.J. Botterweck) (Grand Rapids: Eerdmans 1990) I, 167-188.

Jaubert, A., La date de la cène. Calendrier biblique et liturgie chrétienne (Études Bibliques 15; Paris: Gabalda 1957).

Kondracki, A. (tł.), „Księga Jubileuszów,” Apokryfy Starego Testamentu, wyd. 2 (red. R. Rubinkiewicz) (Prymasowska Seria Biblijna; Warszawa: Vocatio 2000) 262-342.

Lakhmitskaya, T. - Napora, K., „»I widział Bóg, że światło było dobre (Rdz 1,4). Motyw światła w kapłańskim opowiadaniu o stworzeniu (Rdz 1,1-2,4a)", Verbum Vitae 29 (2016) 17-40.

Lemański, J., Księga Rodzaju. Rozdziały 1-11. Wstęp, przekład z oryginału, komentarz (Nowy Komentarz Biblijny Stary Testament 1/1; Częstochowa: Święty Paweł 2013).

Łyczkowska, K., „Enūma Eliš”, Mity akadyjskie (red. M. Kapełuś) (Warszawa: AGADE 2000) $17-50$.

Milgrom, J., Numbers. The Traditional Hebrew Text with the New JPS Translation (The JPS Torah Commentary; Philadelphia, PA - New York: Jewish Publication Society 1990).

Napora, K., „Czas w kapłańskim opowiadaniu o stworzeniu: dzień pierwszy (Rdz 1,3-5)”, Verbum Vitae 35 (2019) 13-37. 
Pawłowski, Z., „Antropologiczne implikacje czasu i przestrzeni w Genesis 1”, Genesis 1-3. Tekst, interpretacje, przemyślenia (red. Z. Pawłowski) (Scripta Theologica Thoruniensia 8; Toruń: Wydawnictwo Naukowe UMK 2009).

Pawłowski, Z., Opowiadanie, Bóg i początek. Teologia narracyjna Rdz 1-3 (Rozprawy i Studia Biblijne 13; Warszawa: Vocatio 2003).

von Rad, G., Die Priesterschrift im Hexateuch: Literarisch Untersucht und Theologisch Gewertet (Beiträge zur Wissenschaft vom Alten und Neuen Testament 65; Stuttgart: Kohlhammer 1934).

von Rad, G., Genesis. A Commentary (The Old Testament Library; Philadelphia, PA: Westminster 1973).

Ricoeur, P., „On the Exegesis of Genesis 1:1-2:4a”, Figuring the Sacred. Religion, Narrative, and Imagination (red. M.I. Wallace) (Minneapolis, MN: Fortress 1995) 129-143.

Rudolph, D.J., Israel's Festivals in the Fourth Day of Creation. The Meaning of מִֹעִ in Genesis 1:14 (Dys. Faculty of Biblical Studies Gordon-Conwell Theological Seminary South Hamilton; Hamilton, MA 2002).

Sarna, N.M., Genesis. The Traditional Hebrew Text with the New JPS Translation (The JPS Torah Commentary; Philadelphia, PA - New York - Jerusalem: Jewish Publication Society 1989).

Sasson, J.M., „Time... To Begin”, “Sha 'Arei Talmon”. Studies in the Bible, Qumran, and the Ancient near East Presented to Shemaryahu Talmon (red. S. Talmon et al.) (Winona Lake, IN: Eisenbrauns 1992) 183-194.

Schmidt, W.H., Die Schöpfungsgeschichte der Priesterschrift, wyd. 2 (Wissenschaftliche Monographien zum Alten und Neuen Testament 17; Neukirchen-Vluyn: Neukirchener 1967).

Skinner, J., Genesis (International Critical Commentary 1; Edinburgh: Clark 1910).

Speiser, E.A., Genesis (Anchor Bible 1; New York: Doubleday 1964).

Tigchelaar, E.J.C., „'Lights Serving as Signs for Festivals' (Genesis 1:14b) in Enûma Eliš and Early Judaism", The Creation of Heaven and Earth (red. G.H. van Kooten) (Leiden: Brill 2005) 31-48.

VanderKam, J.C., Calendars in the Dead Sea Scrolls. Measuring Time (The Literature of the Dead Sea Scrolls; London - New York 2005).

Vogels, W., „The Cultic and Civil Calendars of the Fourth Day of Creation (Gen 1,14b)”, Scandinavian Journal of the Old Testament 11 (1997) 163-180.

Wenham, G.J., Genesis 1-15 (The Word Biblical Commentary 1; Dallas, TX: Word Books 1987).

Westermann, C., Genesis 1-11 (A Continental Commentary; Minneapolis, MN: Fortress 1994). 
